\title{
Downy Brome (Bromus tectorum) Control for Pipeline Restoration
}

\author{
Danielle B. Johnston*
}

\begin{abstract}
Energy-extraction disturbances entail soil handling and often have large edge-to-area ratios. These characteristics should be considered when designing weed-control strategies. In western North America, many energy developments coincide with infestations of downy brome, an annual grass that severely curtails productivity, diversity, and habitat value of invaded areas. Downy brome is sensitive to soil compaction and seed burial, both of which may occur when soil is handled. In this study, I examined the effect of soil-density manipulations and herbicide application (105 g ai $\mathrm{ha}^{-1}$ imazapic with $280 \mathrm{~g}$ ai ha ${ }^{-1}$ glyphosate) on six simulated pipeline disturbances in a Wyoming big sagebrush ecosystem invaded by downy brome. Disturbances occurred at the end of the growing season, after ambient downy brome seed rain in the study areas had abated. Treatments and seeding occurred shortly after disturbances. The following spring, downy brome seedling density was 10 -fold lower within disturbances than in control areas, but seedling density quickly rebounded in disturbed areas where no herbicide had been applied. In herbicide plots, downy brome seedling density remained low during the first growing season, and shrub cover after $3 \mathrm{yr}$ was eight times higher than in no-herbicide plots. Soil density manipulations via disking and rolling treatments had little effect on downy brome. Prior research has shown that imazapic is more effective when combined with disturbances, such as fire. This study demonstrates that imazapic may also be effective in combination with a disturbance that is timed to bury downy brome seeds.
\end{abstract}

Nomenclature: Glyphosate; imazapic ammonium salt; downy brome, Bromus tectorum L. BROTE; Wyoming big sagebrush, Artemisia tridentata Nutt. ssp. wyomingensis Beetle \& Young ARTRW8.

Key words: Cheatgrass, oil and gas development, propagule supply, seed dispersal, soil bulk density, soil compaction.

Rangelands are often threatened by multiple factors (Abu-Sharar 2006; Davies et al. 2011; Durigan et al. 2007). For instance, oil and gas developments may produce networks of disturbances in areas already compromised by invasive species. To prevent such disturbances from becoming vectors for further weed expansion (Bergquist et al. 2007; Durigan et al. 2007), weed-control techniques optimized for oil and gas disturbances must be identified.

Oil and gas disturbances have several characteristics that must be considered when designing weed control and restoration practices. They are composed of many small disturbances with connecting roads and pipelines, producing high edge-to-area ratios. This is important because

DOI: 10.1614/IPSM-D-14-00001.1

* Habitat Researcher, Colorado Parks and Wildlife, Grand Junction, CO, 81505; Affiliate Researcher, Department of Forest and Rangeland Stewardship, Warner College of Natural Resources, Colorado State University, Fort Collins, CO, 80526. Corresponding author's E-mail: danielle.bilyeu@state.co.us small or linear areas are greatly influenced by the seed provided by neighboring plant communities (Bochet et al. 2007; Durigan et al. 2007). Energy-extraction disturbances also require stockpiling topsoil, which lessens soil organic carbon (Anderson et al. 2008; Wick et al. 2009) and kills seeds in the seed bank (Rivera et al. 2012). This is usually undesirable, although it may be helpful if the seed bank contains a large proportion of weed seeds. Finally, the small size and accessibility of these disturbances make them amenable to manipulations requiring heavy equipment, such as tillage or soil amendment.

Oil, gas, and wind energy developments in western North America often occur in sagebrush (Artemisia sp.) ecosystems, which are also threatened by the nonnative, annual grass downy brome (Bromus tectorum L.; Davies et al. 2011). Downy brome poses particular difficulties for restoration because of its phenology and life history traits. Downy brome often germinates in the fall and is capable of extending roots at temperatures as low as $3 \mathrm{C}$ (Harris 1967). By the time more-desirable species germinate, downy brome may have already depleted soil water and nutrients (Harris 1967). Downy brome is also a prolific 


\section{Management Implications}

Downy brome (Bromus tectorum L.) often increases after disturbances, but disturbances that turn the soil over can also be used to help control downy brome because downy brome seeds are sensitive to burial and soil compaction. Success may depend on the timing of the disturbance, and on coupling the disturbance with other measures to help control downy brome. In this experiment, we assessed the effectiveness of $105 \mathrm{~g}$ ai ha ${ }^{-1}$ imazapic plus $280 \mathrm{~g}$ ai ha ${ }^{-1}$ glyphosate coupled with simulated pipeline disturbances. Pipeline disturbances were simulated by scraping vegetation, removing topsoil, and digging trenches, followed by refilling trenches and replacing topsoil. Disturbances occurred in September 2008, directly following the period of downy brome seed distribution for the season. Herbicide application was crossed with tillage treatments (control, disked, rolled, rolled plus disked, and rolled by vibratory drum) applied within pipeline disturbances to further examine how soil compaction affects downy brome. As disturbances occurred in areas already compromised by downy brome, the initial effect of the disturbance was a 10 -fold reduction in downy brome density. Where imazapic was applied, this reduction persisted through the first growing season after the disturbance. Where imazapic was not applied, downy brome densities quickly rebounded to values similar to undisturbed areas. Three years after treatment, downy brome cover was twofold lower and shrub cover was eightfold higher where herbicide had been applied than where it was not applied. The tillage treatments had little effect on downy brome density or cover, possibly because the disturbances themselves had already achieved the goal of burying downy brome seed under slightly compacted soil. In the study area, downy brome seeds distributed throughout the growing season and prior work has shown that downy brome seeds distribute much more readily over bare soils than they do in intact ecosystems. The success of restoration in this study may be related to the disturbances occurring at the end of the growing season. Plant communities disturbed in early spring or summer may be less-easily restored because downy brome seeds from pipeline edges would distribute over the bare soil of the restoration area for a longer period. In practice, it may be impossible to time disturbances at the end of the growing season. When that is the case, one or more of the following strategies may be helpful before fall seeding: (1) treat downy brome patches before disturbance, in a manner that successfully reduces seed production in the area to be disturbed; (2) as soon as the disturbance occurs, line the edges of the disturbed area with a seed-dispersal barrier, such as brush or a trench; (3) control weeds that emerge in the disturbed area before they produce seed; and (4) disk and firm the soil just before planting to bury weed seeds. Actions such as these may complement an application of imazapic by reducing the density of viable downy brome seeds.

seed producer; stands can produce as many as 20,000 seeds $\mathrm{m}^{-2}$ (1,858 seeds $\mathrm{ft}^{-2}$ ) (Hempy-Mayer and Pyke 2008). This is problematic because as few as 40 seeds $\mathrm{m}^{-2}$ can hinder growth of perennial grasses (Evans 1961). Finally, downy brome seed dispersal is enhanced by disturbances that remove vegetation, such as well-pad construction or fire (Johnston 2011; Monty et al. 2013). Because of this, seeds dispersing from the perimeter of small or linear disturbances can occur in sufficient quantities to compromise restoration (Johnston 2011).
However, downy brome also has traits that may be exploited for its control. Downy brome seeds are sensitive to burial; more than $99 \%$ die when buried at $2.5 \mathrm{~cm}(0.99$ in) (Wicks 1997). Downy brome is also less competitive in denser soils (Beckstead and Augspurger 2004; Kyle et al. 2007). In a laboratory study of shallowly buried downy brome seeds, seedling emergence was reduced by 28,52 , and $60 \%$ at soil bulk densities of $1.1,1.2$, and $1.3 \mathrm{~g} \mathrm{~cm}^{-3}$ $\left(0.64,0.69\right.$, and $\left.0.75 \mathrm{oz} \mathrm{in}^{-3}\right)$, respectively, values which permit growth of many desirable plants (Thill et al. 1979). In oil and gas disturbances, both seed burial and soil compaction occur commonly, and it may be possible to use these activities for downy brome control.

The selective herbicide imazapic may also help control downy brome. However, several studies have found that a single application of imazapic alone is insufficient for restoration of native plant communities (Elseroad and Rudd 2011; Morris et al. 2009; Owen et al. 2011). Imazapic has a narrow selectivity window, and good results depend on coupling herbicide application with some form of disturbance (Kyser et al. 2007). Disturbance is helpful because it may remove thatch, thereby aiding the herbicide in making contact with the soil and because it often directly kills or buries downy brome seeds. Without disturbance, rates as high as $210 \mathrm{~g}^{\text {ai ha }}{ }^{-1}\left(2.97 \mathrm{oz} \mathrm{ai} \mathrm{ac}{ }^{-1}\right)$ are needed for a $30 \%$ reduction in downy brome cover (Kyser et al. 2007), and, at such high rates, injury to desirable species may exceed that to downy brome (Baker et al. 2009). With disking, a 30\% downy brome cover reduction requires only $70 \mathrm{~g}$ ai ha ${ }^{-1}$ of herbicide, a rate which avoids injury to many desirable species (Kyser et al. 2007).

The objective of this study was to examine the effect of imazapic herbicide and tillage treatments on plant communities following simulated pipeline disturbances. Disturbances were timed to maximize downy brome seed burial, and then seeded with native grasses, forbs, and shrubs. Sites were within an oil and gas field where Wyoming big sagebrush (Artemisia tridentata Nutt. ssp. wyomingensis Beetle \& Young) communities are threatened by downy brome.

\section{Materials and Methods}

Study Area. The study was conducted at six study sites within the Piceance Basin in Rio Blanco and Garfield counties, $\mathrm{CO}$ (Figure 1), which are currently experiencing extensive natural-gas development. Elevation increases gradually from north to south as one travels from Piceance Creek (approximately $1,800 \mathrm{~m}[5,905.5 \mathrm{ft}]$ ) to the top of the Roan Plateau (approximately 2,500 m), then drops off sharply at the Book Cliffs to the Colorado River Valley (approximately 1,500 m; Figure 1). The six study sites range in elevation from 1,561 to $2,216 \mathrm{~m}$ and are called Grand Valley Mesa (GVM), Ryan Gulch (RYG), SK 


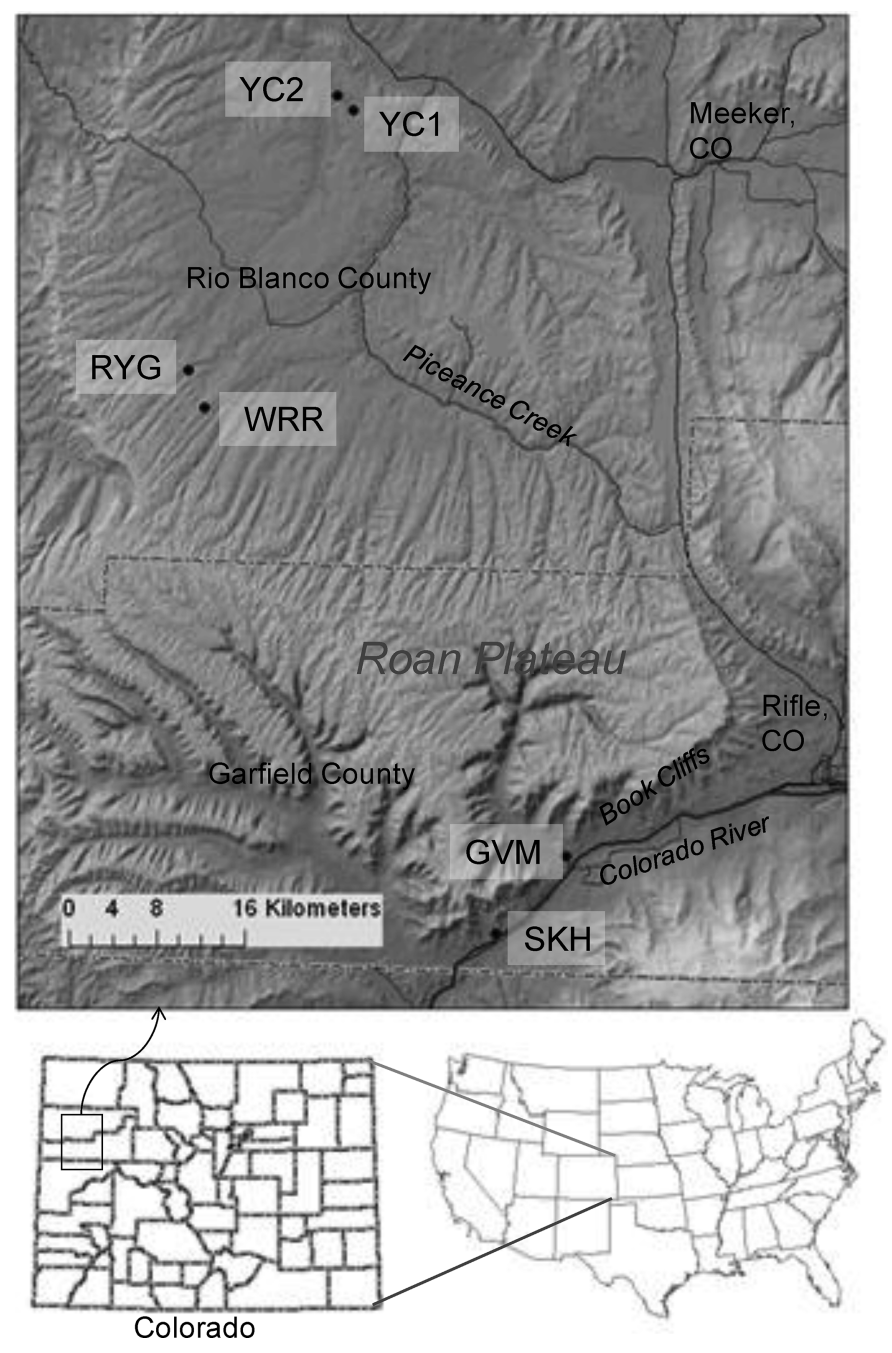

Figure 1. Location of the six study areas within Rio Blanco and Garfield counties, CO.

Holdings (SKH), Wagon Road Ridge (WRR), Yellow Creek 1 (YC1), and Yellow Creek 2 (YC2; Table 1). During the study period, these sites received average annual precipitation of $336 \mathrm{~mm}$ (13 in), 50\% falling during the growing season (Table 1). Study sites shared the following characteristics: slope $<15 \%$, downy brome present, and sagebrush cover $>10 \%$. Sites were dominated by Wyoming big sagebrush, downy brome, Sandberg bluegrass (Poa secunda J. Presl), Indian ricegrass [Achnatherum hymenoides (Roem. \& Schult.) Barkworth], western wheatgrass [Pascopyrum smithii (Rydb.) Á. Löve], prairie junegrass [Koeleria macrantha (Ledeb.) Schult.], and scarlet globemallow [Sphaeralcea coccinea (Nutt.) Rydb]. Soils range from loam to sandy clay loam with 14 to $26 \%$ clay content (Table 2).

Treatments. At each of six sites, two 11 - by $52-\mathrm{m}$, simulated pipeline disturbances were created in late August
2008. A bulldozer was used to scrape the vegetation, pile it off-site, scrape $15 \mathrm{~cm}$ of topsoil, and stockpile topsoil in windrows less than $2 \mathrm{~m}$ high. A backhoe was used to create 1-m-deep trenches, which were left open for 2 wk before being refilled, to mimic the typical duration of pipeline installation (Figure 2). Stockpiled topsoil was spread evenly over each site in mid September 2008.

The study design is a factorial split-plot experiment with two levels of herbicide (herbicide applied or no herbicide) crossed with five levels of tillage. Each pipeline disturbance was a whole plot, and herbicide treatments were randomly assigned to whole plots, which were separated by $15 \mathrm{~m}$ to minimize the effects of herbicide drift. Tillage treatments (control, disked, rolled, disked/rolled, or rolled with vibratory drum) were randomly assigned to subplots within whole plots. Subplots measured 11 by $10 \mathrm{~m}$.

Tillage treatments were completed between mid September and early October 2008. In control plots, bulldozer and backhoe tracks from pipeline recontouring were left in place. Disked plots were disked to $10 \mathrm{~cm}$ with a minidisker pulled behind an all-terrain vehicle (ATV). Rolled plots received one pass with a heavy roller delivering a static load of $36.5 \mathrm{~N} \mathrm{~cm}^{-1}$. Disked/rolled plots were disked to $10 \mathrm{~cm}$, then wetted to $1 \mathrm{~cm}$ using an ATV tow sprayer and rolled five times with a heavy roller delivering a static load of 36.5 $\mathrm{N} \mathrm{cm}{ }^{-1}$. The soil surface was left smooth and crusted with occasional ATV tracks. Vibratory-drum-rolled plots received four passes with a vibratory-drum roller (Wacker RD 12-90, Wacker Neuson, Munich, Germany), and the soil surface was left smooth. These treatments were selected to create a wide range of surface soil densities. The vibratory-drum treatment was not implemented at $\mathrm{YC1}$ or YC2 because of access constraints.

Herbicide was applied between October 6, 2008, and October 22, 2008. Downy brome plants had either not emerged or were at the one-leaf stage (about $5 \mathrm{~cm}$ tall) at the time of application. Because a prior study had shown that postemergence application of imazapic was less effective for downy brome control (Kyser et al. 2007), glyphosate was also applied. A mixture of imazapic (in the form of its ammonium salt, Plateau, BASF Corporation, Ludwigshafen, Germany) at $105 \mathrm{~g}$ ai ha ${ }^{-1}$, glyphosate at $280 \mathrm{~g}$ ai ha ${ }^{-1}$ (Killzall, Hi-Yield, Voluntary Purchasing Groups, Inc., Bonham, TX), and methylated seed oil (2\% $\mathrm{v} / \mathrm{v})$ were applied using an ATV tow sprayer with a boom (45-0424 sprayer, Agri-Fab, Sullivan, IL).

All treatments were seeded with the same a mixture of native shrubs, grasses, and forbs (Table 3). Several species were Colorado Plateau ecotypes in development for production by the Uncompahgre Partnership (Montrose, CO) (Table 3). Sites were seeded in October 2008 using a rangeland drill (Tye Pasture Pleaser, company defunct) calibrated to plant seed $1 \mathrm{~cm}$ deep in tilled soil. Grasses and saltbush (Atriplex spp.) species were mixed together, 
Table 1. Study site description and precipitation information for the six study sites. ${ }^{\mathrm{a}}$

\begin{tabular}{|c|c|c|c|c|c|c|c|c|c|}
\hline \multirow[b]{3}{*}{ Site $^{\mathrm{b}}$} & \multirow[b]{3}{*}{ Elevation } & \multirow[b]{3}{*}{ Topography } & \multicolumn{7}{|c|}{ Precipitation } \\
\hline & & & \multicolumn{2}{|c|}{2009} & \multicolumn{3}{|c|}{2010} & \multicolumn{2}{|c|}{2011} \\
\hline & & & Summer & Fall & Winter/spring & Summer & Fall & Winter/spring & Summer \\
\hline & $\mathrm{m}$ & & & & & $-\mathrm{mm}$ & & & \\
\hline GVM & 1,662 & Top of mesa & 88.6 & 38.2 & 151.6 & 68.4 & 95.8 & 85.2 & 198.4 \\
\hline RYG & 2,084 & $\begin{array}{l}\text { Narrow-gulch } \\
\text { bottom }\end{array}$ & 60.4 & 92.4 & 163.8 & 112.2 & 82.6 & 122.8 & 243.4 \\
\hline SKH & 1,561 & $\begin{array}{l}\text { Broad-valley } \\
\text { bottom }\end{array}$ & 79.6 & 39.2 & 125.6 & 52.8 & 109.8 & 70.2 & 196.2 \\
\hline WRR & 2,216 & Wide-ridge top & 62.3 & 57.9 & $-^{c}$ & 106.2 & 66.0 & 110.8 & 189.0 \\
\hline YC1 & 1,905 & $\begin{array}{c}\text { Narrow-valley } \\
\text { bottom }\end{array}$ & 70.0 & 57.8 & 133.0 & 133.6 & 85.8 & 102.2 & 155.4 \\
\hline YC2 & 1,829 & $\begin{array}{l}\text { Broad-valley } \\
\text { bottom }\end{array}$ & 65.8 & 62.6 & 152.6 & 183.6 & 97.2 & 110.4 & 177.4 \\
\hline
\end{tabular}

${ }^{a}$ Summer data are June to August, fall data are September to November, and winter/spring data are December to May. Precipitation data were recorded at 2-mm intervals using RG3-M data-logging rain gauges (Onset Computer Corporation, Bourne, MA) installed on guyed $1.5-\mathrm{m}$ posts at each site.

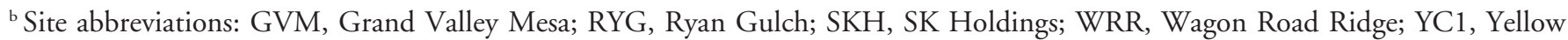
Creek 1; YC2, Yellow Creek 2, within the Piceance Basin in Rio Blanco and Garfield counties, CO.

${ }^{\mathrm{c}}$ Data not available because of logger failure.

as were all forb species, and rice hulls were added to maintain suspension of differently sized seeds. Grass/ Atriplex and forb mixtures were separated into alternating rows by placing dividers in the seed box to lessen competition between forbs and grasses. Locally collected Wyoming big sagebrush seed was hand-broadcast over snow in mid-January. In fall 2008, 2.4-m-high fencing was established around each study site. Standardized, ungrazed conditions were created because two of the cattle ranchers in the study area indicated that grazing might or might not continue for the duration of the study and because native-ungulate densities varied widely between sites.

Vegetation and Soil Assessment. Ambient downy brome seed rain was quantified using $0.1 \mathrm{~m}^{2}\left(155 \mathrm{in}^{2}\right)$ plywood, seed-rain traps covered with Tree Tanglefoot (The Tanglefoot Company, Grand Rapids, MI) placed in eight systematically chosen, undisturbed locations at each site. Downy brome seeds were counted and removed from traps a mean of every $12 \mathrm{~d}$ from mid May to early September 2009 to 2011. Tanglefoot was reapplied as necessary to ensure a sticky surface. Seeds caught per square meter per Julian date were calculated and then averaged over years for each site.

In May and July of 2009, downy brome seedling counts were conducted. Nine microplots were sampled in un- disturbed vegetation near the study sites, placed at systematic intervals $10 \mathrm{~m}$ from the edge of the research area. Nine microplots were also sampled within each subplot, placed systematically with one microplot in the center of the subplot, and the remaining microplots equidistant from the center microplot and either a subplot corner or the midpoint of a subplot edge. Microplot size was $300 \mathrm{~cm}^{2}\left(46.5 \mathrm{in}^{2}\right)$, except where seedlings were sparse; in which case, microplot size was increased to $3,000 \mathrm{~cm}^{2}$ to ensure detection of sparse seedlings. The number of seedlings per square meter was calculated for each microplot and then averaged to the plot level.

In 2010 and 2011, the percentage of cover by all species was recorded on five systematically placed $1-\mathrm{m}^{2}$ microplots per subplot. A grid containing 36 intersections was held over each microplot, and point-intercept hits were measured at each grid intersection using a laser pointintercept sampling device (Synergy Resource Solutions, Bozeman MT). All species hit were recorded for each point, but when calculating the percentage of cover by a given functional group (downy brome, annual forbs, perennial grasses, perennial forbs, or shrubs), overlapping hits of different species within a functional group (for instance, western wheatgrass overlying Sandberg bluegrass) were counted as a single instance of the functional group.

Soil bulk-density samples were used to compare sites and to compare disturbed vs. undisturbed locations. Bulk 


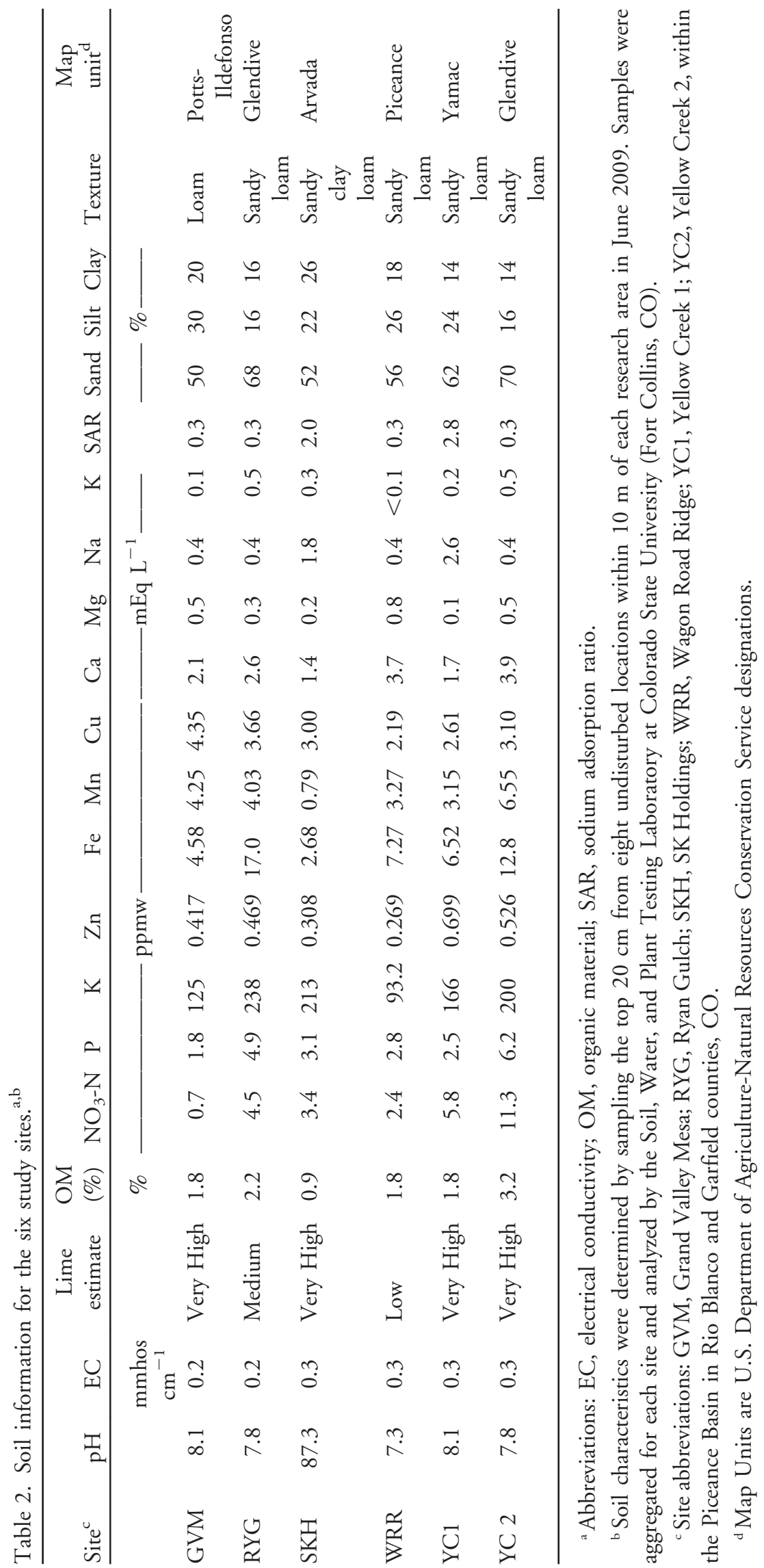




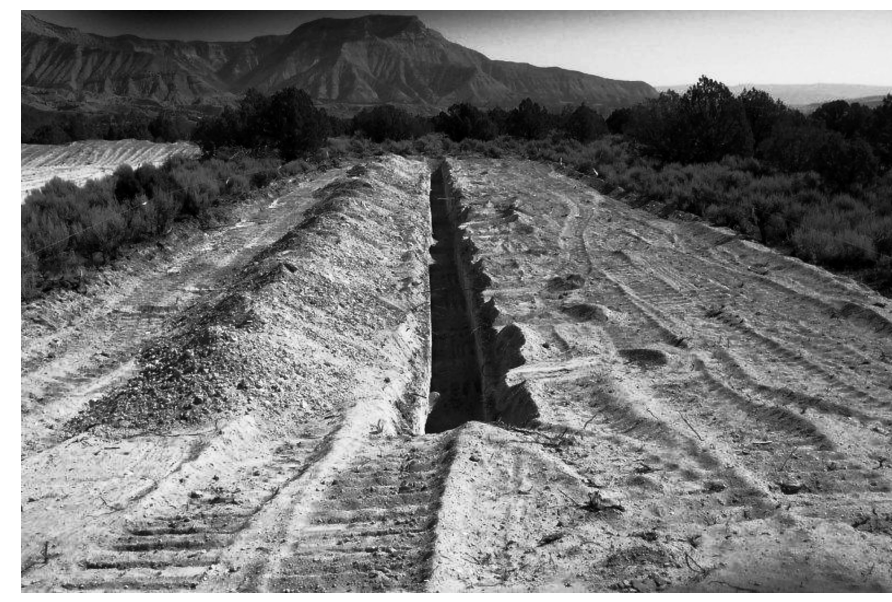

Figure 2. Pipeline disturbance simulation at the Grand Valley Mesa site.

density samples were taken in haphazardly selected locations in September 2008 using a 30.5-cm, drop-hammer, doublecylinder core sampler fitted with six abutting $5.1 \mathrm{~cm}$-long inner cylinders. Five cores were taken in undisturbed areas near each site, and six cores, three in each control soil-tillage subplot, were taken within pipeline disturbances. Cores were divided into six depth fractions by removing the abutting inner cylinders from the sampler, then inserting a piece of metal flashing between adjoining cylinders. The dry weight of each fraction was divided by its volume to find its bulk density.

Jornada cone penetrometer resistance (Herrick and Jones 2002) was used to quantify within-site soil density differences among tillage plots. Penetrometer resistance correlates with bulk density but is a more easily obtained metric (Thompson et al. 1987). Five systematically placed penetrometer measurements were taken in each subplot in May 2009. The number of hammer drops required to move the penetrometer through the soil was recorded for each $5-\mathrm{cm}$ depth increment from $4 \mathrm{~cm}$ to $29 \mathrm{~cm}$, and the force required to penetrate the soil was calculated for each depth fraction.

Analysis. ANOVA in SAS PROC MIXED (SAS Institute Inc., Cary, NC) was used to analyze differences in

Table 3. Seed mixture. ${ }^{\mathrm{a}}$

\begin{tabular}{|c|c|c|c|c|}
\hline Scientific name & Common name & $\begin{array}{c}\text { Source or } \\
\text { variety }\end{array}$ & PLS & Live seeds \\
\hline \multicolumn{3}{|l|}{ Forbs } & \multicolumn{2}{|c|}{$\mathrm{kg} \mathrm{ha}^{-1}$ seeds $\mathrm{m}^{-2}$} \\
\hline Achillea millefolium var. occidentalis DC. & Western yarrow & UP & 0.11 & 67 \\
\hline Eriogonum umbellatum Torr & Sulfur-flower buckwheat & UP & 1.16 & 53 \\
\hline Hedysarum boreale Nutt. & Utah sweetvetch & UP & 0.49 & 11 \\
\hline Heterotheca villosa (Pursh) Shinners & Hairy false goldenaster & UP & 1.25 & 137 \\
\hline Linum lewisii Pursh & Lewis flax & Maple Grove & 0.43 & 28 \\
\hline \multicolumn{5}{|l|}{ Packera multilobata (Torr. \& A. Gray ex A. Gray) } \\
\hline W.A. Weber \& Á. Löve & Lobeleaf groundsel & UP & 0.11 & 67 \\
\hline Penstemon strictus Benth. & $\begin{array}{l}\text { Rocky Mountain } \\
\text { penstemon }\end{array}$ & Bandera & 0.37 & 23 \\
\hline \multicolumn{5}{|l|}{ Grasses } \\
\hline Achnatherum hymenoides (Roem. \& Schult.) Barkworth & Indian ricegrass & Nezpar & 0.93 & 33 \\
\hline Elymus trachycaulus (Link) Gould ex Shinners & Slender wheatgrass & San Luis & 0.27 & 10 \\
\hline Elymus elymoides (Rafin.) Swezey & Squirreltail & Toe Jam Creek & 0.51 & 21 \\
\hline Koeleria macrantha (Ledeb.) Schult. & Prairie junegrass & UP & 0.2 & 105 \\
\hline Nassella viridula (Trin.) Barkworth & Green needlegrass & Lodorm & 0.76 & 22 \\
\hline Pascopyrum smithii (Rydb.) Á. Löve & Western wheatgrass & Rosana & 0.45 & 11 \\
\hline Poa secunda J. Presl & Sandberg bluegrass & UP & 0.29 & 68 \\
\hline Pseudoroegneria spicata (Pursh) Á. Löve & Bluebunch wheatgrass & P-7 & 0.41 & 10 \\
\hline Pseudoroegneria spicata (Pursh) Á. Löve & Bluebunch wheatgrass & Secar & 0.42 & 11 \\
\hline \multicolumn{5}{|l|}{ Shrubs } \\
\hline $\begin{array}{l}\text { Artemisia tridentata Nutt. ssp. Wyomingensis Beetle \& } \\
\quad \text { Young }\end{array}$ & Wyoming big sagebrush & Local collection & 0.37 & 246 \\
\hline Atriplex canescens (Pursh) Nutt. & Fourwing saltbush & VNS & 0.61 & 7 \\
\hline Atriplex confertifolia (Torr. \& Frém.) S. Wats. & Shadscale & VNS & 0.53 & 7 \\
\hline Total & & & 9.66 & 937 \\
\hline
\end{tabular}

${ }^{a}$ Abbreviations: PLS, pure live seed; UP, Uncompaghre Partnership (http://www.UPartnership.org); VNS, variety not stated. 


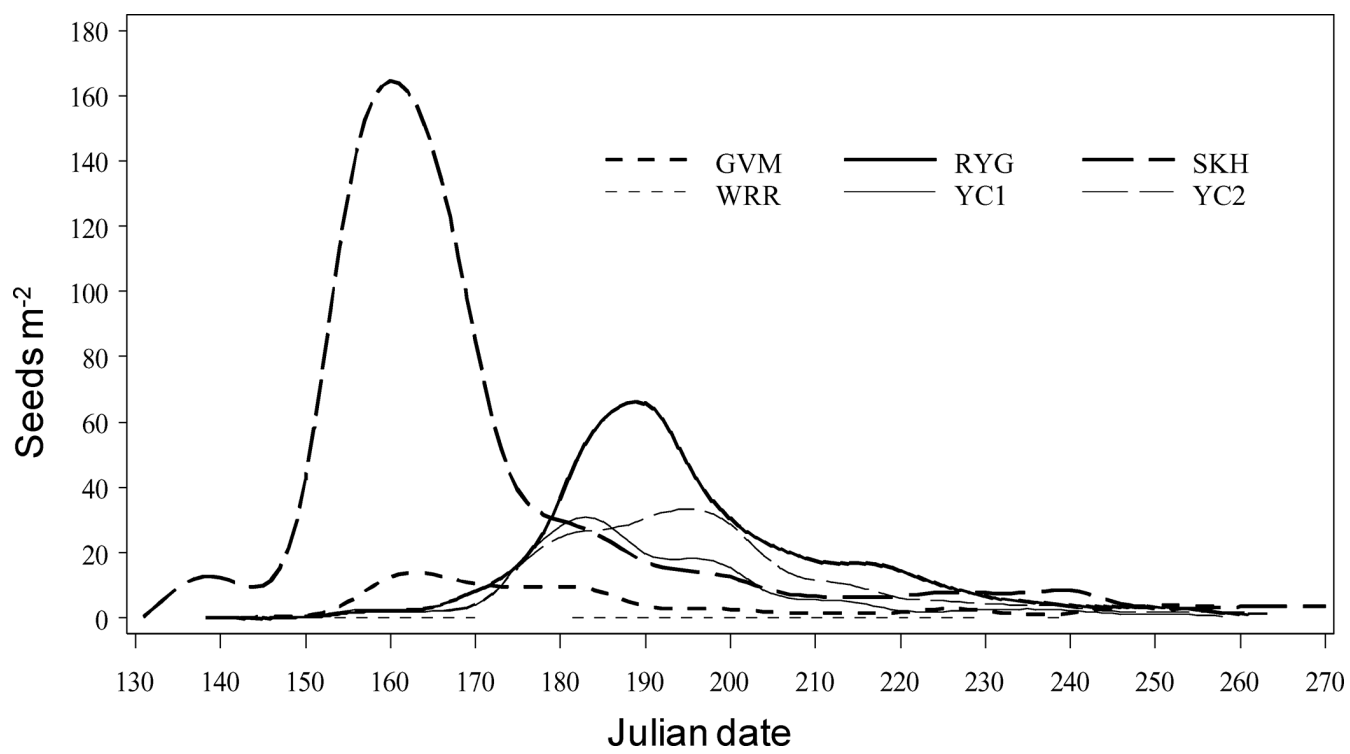

Figure 3. Prevalence of downy brome seeds between May and September in undisturbed locations near the six study sites. Data are averages throughout $3 \mathrm{yr}$ (2009 to 2011). The data were smoothed using a cubic spline (Reinsch 1967) with SAS/GRAPH software using an $n n$ value of 15 (SAS Institute Inc 2012).

responses to treatments. Site was considered a random effect. For bulk density, separate analyses were done for each depth fraction, and the fixed effect was a location variable (on or off pipeline). For penetration resistance, separate analyses were done for each depth fraction, and the fixed effects were the soil tillage treatments. For cover data, biennial forbs were lumped with annual forbs, data were transformed by an arcsine $[\sqrt{x}]$ to improve normality, and functional groups were analyzed separately. For density and cover data, repeated-measures ANOVA was performed, with a site by herbicide random effect to account for the split-plot design. Fixed effects were time (season if density data, year if cover data), treatments (disking, rolling, vibration, and herbicide), and an a priori set of possible interactions: each tillage treatment (disking, rolling, and vibration) was allowed to interact with the herbicide treatment, disking was allowed to interact with rolling, and time was allowed to interact with all treatments as well as the aforementioned two-way interactions. Subplots receiving the vibratory-drum-roll treatment were considered to have received both vibration and rolling. The final model was determined using a backward selection process with a cutoff value of $\alpha=$ 0.05 for means and $\alpha=0.10$ for interactions. Linear regression was used to examine the relationship between soil-penetration resistance and downy brome seedling density and cover, using only nondisked plots without the herbicide treatment. Effect sizes are presented with $95 \%$ confidence intervals.

\section{Results and Discussion}

Ambient downy brome seed rain in the study areas peaked between early June and mid July, and then tapered off by early September (Figure 3). Peak values varied from 160 seeds $\mathrm{m}^{-2} \mathrm{~d}^{-1}$ at SKH to 1 seed $\mathrm{m}^{-2} \mathrm{~d}^{-1}$ at WRR (Figure 3).

In undisturbed locations near study sites during 2009, downy brome seedling density was $506 \pm 216$ plants $\mathrm{m}^{-2}$ in May and $139 \pm 75$ plants $\mathrm{m}^{-2}$ in July (Figure 4). In treatment plots, downy brome seedling density depended on an interaction between herbicide and season $(\mathrm{P}<0.0001)$. Seedling density increased from 41 to 201 plants $\mathrm{m}^{-2}$ from May to July in plots without herbicide $(\mathrm{P}<0.0001 ;$ Figure 4$)$, but in herbicide plots, seedling density remained lower than in undisturbed locations (Figure 4). Downy brome seedling density in treatment plots also depended on an interaction between herbicide and disking treatment $(P=0.03)$. In the absence of herbicide, disking reduced downy brome seedling density from 53 to 23 plants $\mathrm{m}^{-2}$ in May $(\mathrm{P}=0.008)$ and from 243 to 139 plants $\mathrm{m}^{-2}$ in July $(\mathrm{P}=0.002)$. In the presence of herbicide, there was no effect of disking in either month $(\mathrm{P}>0.32)$.

Downy brome cover was influenced by year $(P=0.03)$, a strong main effect of herbicide $(\mathrm{P}=0.003)$, and an interaction between disking and herbicide $(\mathrm{P}=0.02$; Table 4). Averaged across treatments, downy brome cover increased from $32.9 \%$ in 2010 to $40.0 \%$ in 2011. Averaged across years and tillage treatments, downy brome 


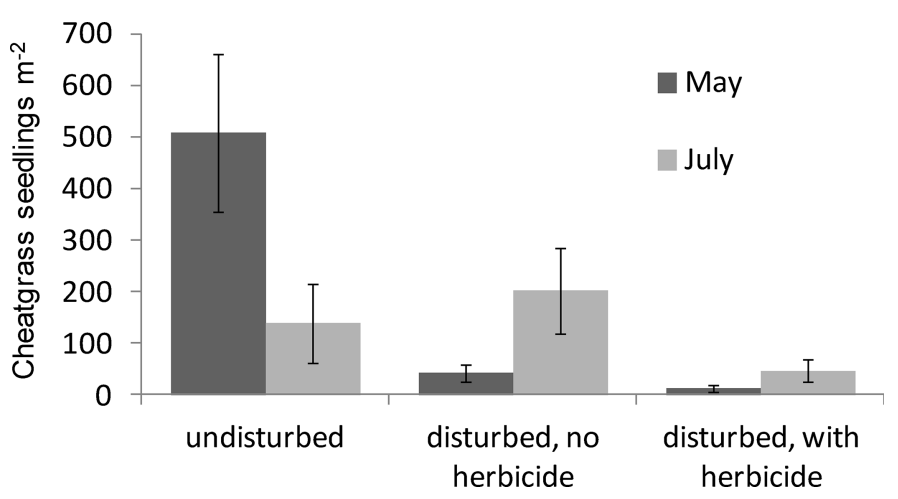

Figure 4. Downy brome seedling density in 2009 in undisturbed locations and by herbicide treatment within disturbances. Data within disturbances are averaged over tillage treatment. Error bars $=S E$ of the six study sites.

cover was $52.1 \%$ in plots without herbicide and $21.6 \%$ in plots with herbicide. Disking tended to produce opposite effects depending on whether or not herbicide was applied, although individual contrasts of means were not significant. With herbicide, disking may have increased downy brome cover, from a mean of 17.6 to $25.7 \%(P=0.06)$. In the absence of herbicide, disking may have decreased downy brome cover, from 54.6 to $47.8 \%(\mathrm{P}=0.10)$.

Perennial grass cover was influenced by disking $(\mathrm{P}=$ $0.01)$ and by year $(P=0.002$; Table 4$)$. Perennial grass cover increased from $21.5 \%$ in 2010 to $27.5 \%$ in 2011 . Averaged over years, perennial grass cover was $26.1 \%$ in disked plots and $22.9 \%$ in nondisked plots. Perennial forb cover was not influenced by any factors $(\mathrm{P}>0.20$; Table 4). Annual forb cover was not influenced by any treatments, but dropped from $26.0 \%$ in 2010 to $16.6 \%$ in 2011 (year effect $\mathrm{P}=0.0006$; Table 4).

Shrub cover was influenced by an interaction between herbicide and year $(P=0.001$; Figure 5$)$ and a likely interaction between herbicide and rolling treatment $(\mathrm{P}=$ 0.06). In 2010, no herbicide effect was evident $(P=0.24)$, and shrub cover averaged $1.5 \%$. In 2011, shrub cover depended on herbicide treatment $(\mathrm{P}=0.002)$ with $9.1 \%$ shrub cover in herbicide plots and $1.2 \%$ shrub cover in noherbicide plots (Figure 5). Rolling had no apparent effect in the absence of herbicide $(\mathrm{P}=0.75)$ but with herbicide, shrub cover dropped from $7.7 \%$ in not-rolled plots to $4.0 \%$ in rolled plots $(\mathrm{P}=0.02)$.

The creation of the simulated pipeline disturbances increased soil bulk density by $0.13 \pm 0.05 \mathrm{~g} \mathrm{~cm}^{-3}$. The

Table 4. Cover of functional groups in response to herbicide and tillage treatments imposed in 2008 , averaged over 6 study sites. ${ }^{a}$

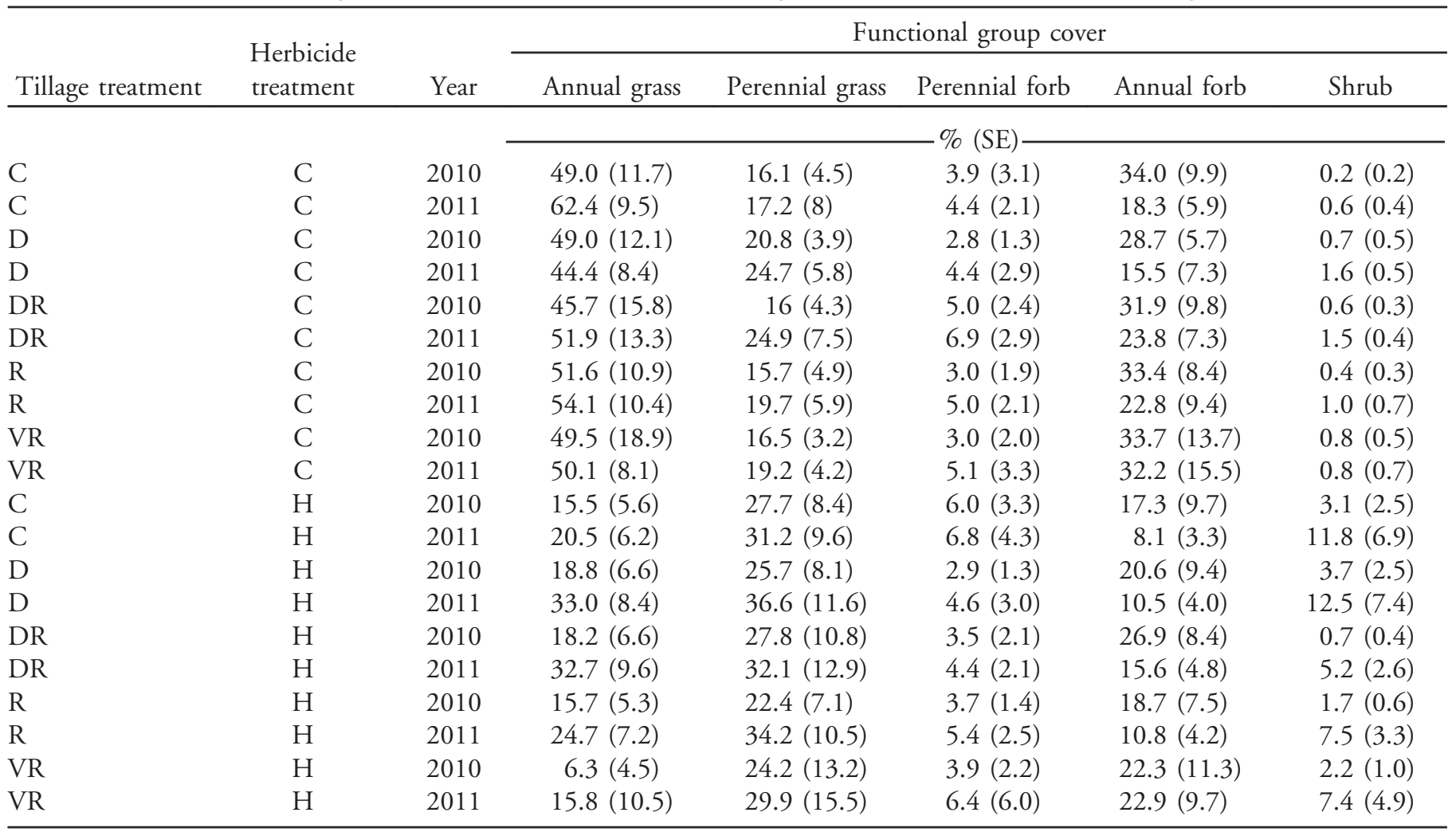

a Abbreviations: C, control; D, disked; DR, disked and rolled; R, rolled; VR, rolled with vibratory drum; H, herbicide (imazapic [105 $\mathrm{g}$ ai ha $\left.^{-1}\right]$ and glyphosate $\left[280 \mathrm{~g}\right.$ ai ha $\left.\left.{ }^{-1}\right]\right)$. 


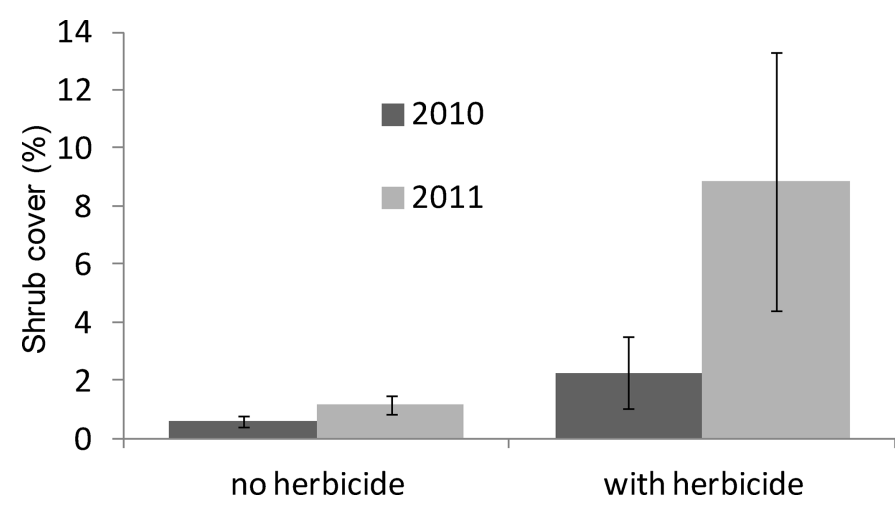

Figure 5. Shrub cover in 2010 and 2011 by herbicide treatment. Data are averaged over sites and tillage treatments. Error bars $=\mathrm{SE}$.

increase in bulk density was evident at all depth fractions, except the 5 to $10 \mathrm{~cm}$ depth fraction $(\mathrm{P}<0.01$, Figure 6$)$. Bulk density also varied across study sites with the discrepancy between the two most-disparate sites, RYG and SKH, being $0.29 \pm 0.08 \mathrm{~g} \mathrm{~cm}^{-3}$. Off-pipeline, bulk density in the uppermost depth fraction varied from 0.64 to $1.41 \mathrm{~g} \mathrm{~cm}^{-3}$ with a mean of $1.06 \mathrm{~g} \mathrm{~cm}^{-3}$. On-pipeline, bulk density in the uppermost depth fraction varied from 0.77 to $1.52 \mathrm{~g} \mathrm{~cm}^{-3}$ with a mean of $1.21 \mathrm{~g} \mathrm{~cm}^{-3}$ (Figure 6).

The soil tillage treatments significantly affected soil penetration resistance (Figure 7). For the 4 to $9 \mathrm{~cm}$ depth fraction, the soil had $99 \pm 34 \mathrm{~N}$ greater resistance in the vibratory drum treatment than in the control, $134 \pm 29 \mathrm{~N}$ less resistance in the disked treatment than in the control, and $74 \pm 29 \mathrm{~N}$ less resistance in the disked/rolled treatment than in the control (Figure 7a). For the 9- to 14-cm-depth fraction, the vibratory drum treatment had $163 \pm 64 \mathrm{~N}$ more resistance than the control, and the disked treatment had $171 \pm 56 \mathrm{~N}$ less resistance than the control (Figure 7b). For the 14- to 19-cm-depth fraction, penetration resistance was $230 \pm 107 \mathrm{~N}$ greater in the vibratory drum treatment than in the control (Figure 7c). Differences were not evident for any treatment at depths greater than $19 \mathrm{~cm}$, and the rolled treatment was not significantly different from the control at any depth. Soil penetration resistance did not correlate with downy brome seedling density in May $\left(R^{2}=0.08 ; \mathrm{P}=0.27\right)$ or July $\left(R^{2}\right.$ $=0.05 ; \mathrm{P}=0.43)$ of 2009 . Soil penetration resistance did not correlate with downy brome cover in $2010\left(R^{2}=0.03\right.$; $\mathrm{P}=0.37)$ or $2011\left(R^{2}=0.02 ; \mathrm{P}=0.43\right)$.

The pipeline disturbances increased soil bulk density to 1.1 to $1.2 \mathrm{~g} \mathrm{~cm}^{-2}$, which is near the 1.2 to $1.3 \mathrm{~g} \mathrm{~cm}^{-2}$ range shown previously to impede downy brome emergence (Thill et al. 1979). The spring following disturbance, downy brome density was 10-fold lower within disturbances than it was in undisturbed areas. However, that reduction in density was short lived in the

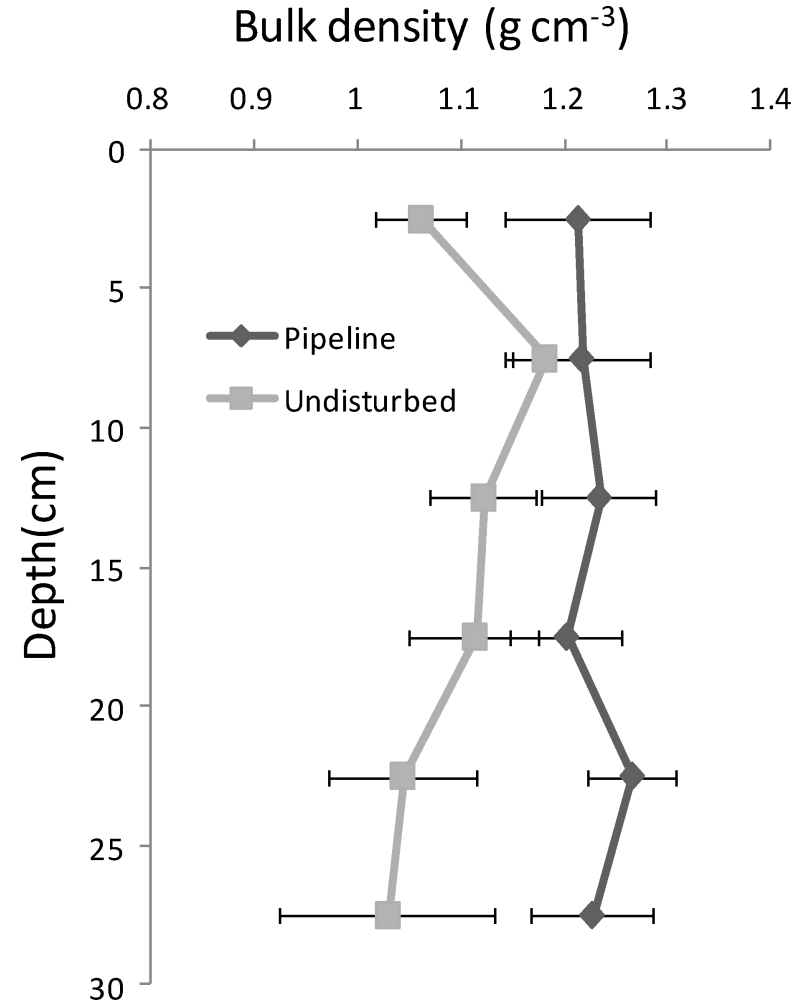

Figure 6. Bulk density in undisturbed areas near pipeline disturbances and in pipeline control plots. Error bars $=\mathrm{SE}$.

plots without herbicide, which rebounded by July 2009 to densities similar to undisturbed areas (Figure 4). In the plots with herbicide, downy brome density remained low throughout the first growing season (Figure 4). Three years after treatment, downy brome cover in herbicide plots was half that in no-herbicide plots. Shrub cover was eightfold greater in plots with herbicide, and grass and forb cover were similar between herbicide plots and no-herbicide plots.

These results contrast with some other studies in Wyoming big sagebrush plant communities, in which downy brome cover in plots where imazapic herbicide was applied rebounded to levels as high (Owen et al. 2011) or higher (Morris et al. 2009) than that of control plots in 2 to $3 \mathrm{yr}$, or in which imazapic negatively affected forbs (Baker et al. 2009; Owen et al. 2011). Prior work has shown that imazapic is more effective for annual grass control when applied after disturbances, such as burning (Davies and Sheley 2011; Sheley et al. 2007). This study suggests that a properly timed soil disturbance, such as a pipeline installation, can provide a similar function. These disturbances removed thatch, which likely aided the herbicide in reaching the soil surface (Davies and Sheley 2011; DiTomaso 2000; Kyser et al. 2007; Sheley et al. 2007). In addition, the disturbances likely buried many downy brome seeds under soil too dense for downy brome seedlings to penetrate. 


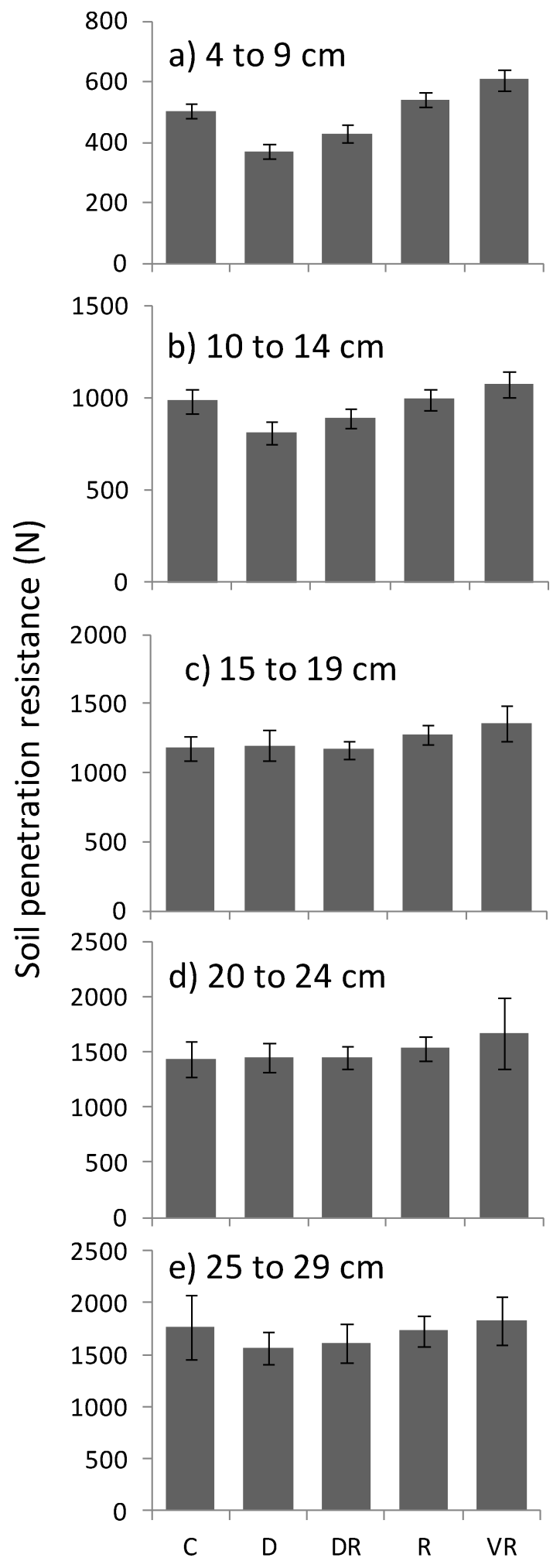

Figure 7. Soil-penetration resistance by soil-tillage treatment at depths of (a) 4 to $9 \mathrm{~cm}$, (b) 10 to $14 \mathrm{~cm}$, (c) 15 to $19 \mathrm{~cm}$, (d) 20 to $24 \mathrm{~cm}$, and (e) 25 to $29 \mathrm{~cm}$. Abbreviations: C, control; D, disked; DR, disked and rolled; R, rolled; and VR, rolled with vibratory drum compactor. Error bars $=\mathrm{SE}$ for 12 plots, two at each of six sites. Note differing y-axis scales.
The rate of imazapic used in this study is the same as, or lower than, that used in several other studies where a single rate was tested (Baker et al. 2009; Owen et al. 2011, Sbatella et al. 2011). In a review of many studies with application rates varying from 70 to $211 \mathrm{~g}$ ai ha ${ }^{-1}$, the rate used in this study $\left(105 \mathrm{~g}_{\text {ai ha }}{ }^{-1}\right)$ was determined to be the lowest which provided at least short-term downy brome control (Mangold et al. 2013). Higher rates provided more-complete (Mangold et al. 2013) and longer-lasting (Morris et al. 2009) control, but also reduced the establishment rate of desirable species (Morris et al. 2009). Thorough control of downy brome is needed because downy brome plants efficiently increase productivity to compensate for low density. Stands with only 50 plants $\mathrm{m}^{-2}$ may have similar biomass and produce similar numbers of seeds as stands with 2,000 plants $\mathrm{m}^{-2}$ (Hulbert 1955). Thus, downy brome seed banks can quickly recover from dramatic reductions (Humphrey and Schupp 2001), and measures that only partially control downy brome are sometimes insufficient for restoration (Morris et al. 2009; Owen et al. 2011). As the rate of imazapic application cannot be increased without injury to desirable species, it follows that complementary measures are needed to reduce downy brome propagule pressure.

Ambient downy brome seed distribution peaked in June and continued until September during the course of this study (Figure 3). Although downy brome seed abscission occurs during a much shorter window (May to June), prior research has shown that only about one-half of downy brome seeds remain in a particular location upon landing there (Kelrick 1991). This leads to a long, gradually tapering availability of downy brome seeds during the course of a growing season (Figure 3). Bare soil areas surrounded by downy brome are vulnerable to colonization during this time, particularly if they have high edge-to-area ratios. Downy brome seeds travel more readily over bare soils than through intact sagebrush ecosystems, and enough seeds may disperse from the edges of small or linear disturbances to compromise restoration (Johnston 2011). Together, these prior studies suggest that the success of restoration in this study may have been related to the timing of the disturbance. The pipeline disturbances occurred in September 2008; therefore, bare soils were not exposed during most of the 2008 growing season. Topsoil removal, stockpiling, and replacement likely buried most downy brome seeds within the disturbed area, and species seeded in fall 2008 were able to germinate before 2009 downy brome seeds began dispersing. Disturbances occurring earlier in the growing season may be more difficult to restore.

In this study, big sagebrush comprised $72 \%$ of all shrub cover in 2010, and $78 \%$ in 2011. In a study of competitive dynamics between downy brome and big sagebrush, 
sagebrush and downy brome competed for soil water, and downy brome cover increased when sagebrush was removed (Prevey et al. 2010). In plots where herbicide was applied, sagebrush appears to have established well enough to limit downy brome cover, resulting in a long-term effect of herbicide application on the plant community.

The disking treatment reduced initial downy brome seedling density and improved perennial grass cover. The effect on downy brome seedling density was due, in part, to directly killing germinating downy brome plants, as disking was applied near the time of downy brome emergence. Disking likely improved perennial grass cover by relieving compaction of the rooting zone, which can restrict root growth and compromise establishment of deeply rooted perennial plants (Thompson et al. 1987). However, there was no main effect of disking on downy brome cover 2 and 3 yr after treatment. Disturbances that reduce soil compaction tend to increase downy brome (Beckstead and Augspurger 2004), which may explain why disking had only a short-term effect. Also, it is possible that disking just before fall seeding may be more beneficial if the initial disturbance occurs earlier in the growing season because disking may aid in burial of downy brome seeds that settled in the restoration area in the intervening time.

The goal of the rolling treatments was to increase soil bulk density to 1.2 to $1.3 \mathrm{~g} \mathrm{~cm}^{-3}$ because bulk densities in this range may reduce downy brome emergence by 52 to $60 \%$ (Thill et al. 1979). However, the pipeline disturbances themselves increased bulk density to near the target range, and there was no additional benefit realized from the rolling treatments. Although rolling affected soil-penetration resistance, there was no correlation between soil penetration resistance and downy brome seedling density or cover. Rolling also had a negative effect on 2011 shrub cover and is, therefore, not recommended.

The inclusion of glyphosate with the imazapic treatment likely had little effect on the outcome of this study. Glyphosate was included to kill existing downy brome plants because downy brome had emerged at some sites at the time of application, and a prior study had shown that imazapic was less effective when applied postemergence (Kyser et al. 2007). However, subsequent research has shown that, when imazapic is applied early postemergence, as it was in this study, it is actually more effective than when applied preemergence (Mangold et al. 2013). Another study has shown that a glyphosate application before fall planting, at double the rate used in this study, does not control downy brome as well $70 \mathrm{~g}^{\mathrm{ai} \mathrm{ha}}{ }^{-1}$ of imazapic, a lighter application than used in this study (Ostlie and Howatt 2013). Glyphosate is only effective at the time of application, and that is also when the efficacy of imazapic is highest. Therefore, the effect of glyphosate on downy brome control was probably redundant to that of the imazapic.
In summary, downy brome control in pipeline restoration may be aided by using imazapic and likely also by using the disturbance itself to bury as many downy brome seeds as possible. In the case of pipeline construction, it may not always be possible to time disturbances for maximum seed burial. If the disturbance must occur in the spring or summer, it may be advisable to protect the site from downy brome seed rain, possibly with dispersal obstructions or weed control in the adjacent area.

The use of disturbances to aid in downy brome control requires a thorough understanding of starting conditions as well as the nature and timing of the disturbance. Many studies have documented that disturbances can aid in downy brome expansion because downy brome can quickly garner the resources made available by disturbances (Beckstead and Augspurger 2004; Bradford and Lauenroth 2006; Roundy et al. 2007). A disturbance in an intact, functioning ecosystem is unlikely to improve conditions. However, when a disturbance occurs in an area already compromised by downy brome, a thoughtful approach is to use the disturbance itself to bury downy brome seeds and to enhance the effectiveness of imazapic herbicide. Such measures may lessen downy brome propagule pressure sufficiently for desirable plants to establish.

\section{Acknowledgments}

I thank Julie Beckstead and Rob Raley for assistance and advice, and J. C. Rivale for logistical support. Ruth Bennett, Robert Wayne, Melissa Neubaum, Neil LaFleur, Katie Kain, Noelle Guernsey, John Giesentanner, Anna Mangan, Chad Young, Alicia Lucero, and Daniel Jarmolowicz provided field assistance. Tony Apa, Dan Tripp, Walter Johnston, and two anonymous reviewers provided helpful revisions. Encana Oil and Gas, Shell Oil Company, and WPX Energy provided funding.

\section{Literature Cited}

Abu-Sharar TM (2006) The challenges of land and water resources degradation in Jordan: Diagnosis and solutions. Pages 201-226 in Kepner WG, Rubio JL, Mouat DA, Pedrazzini F, eds. Desertification in the Mediterranean region: a security issue. Cham, Switzerland: Springer

Anderson JD, Ingram LJ, Stahl PD (2008) Influence of reclamation management practices on microbial biomass carbon and soil organic carbon accumulation in semiarid mined lands of Wyoming. Appl Soil Ecol 40:387-397

Baker WL, Garner J, Lyon P (2009) Effect of imazapic on cheatgrass and native plants in Wyoming big sagebrush restoration for Gunnison sage-grouse. Nat Area J 29:204-209

Beckstead J, Augspurger CK (2004) An experimental test of resistance to cheatgrass invasion: limiting resources at different life stages. Biol Invasions 6:417-432

Bergquist E, Evangelista P, Stohlgren TJ, Alley N (2007) Invasive species and coal bed methane development in the Powder River Basin, Wyoming. Environ Monit Assess 128:381-394 
Bochet E, Garcia-Fayos P, Tormo J (2007) Road slope revegetation in semiarid Mediterranean environments, part I: seed dispersal and spontaneous colonization. Restor Ecol 15:88-96

Bradford JB, Lauenroth WK (2006) Controls over invasion of Bromus tectorum: the importance of climate, soil, disturbance and seed availability. J Veg Sci 17:693-704

Davies KW, Sheley L (2011) Promoting native vegetation and diversity in exotic annual grass infestations. Restor Ecol 19:159-165

Davies KW, Boyd CS, Beck JL, Bates JD, Svejcar TJ, Gregg MA (2011) Saving the sagebrush sea: an ecosystem conservation plan for big sagebrush plant communities. Biol Conserv 144:2573-2584

DiTomaso JM (2000) Invasive weeds in rangelands: species, impacts, and management. Weed Sci 48:255-265

Durigan G, de Siqueira MF, Franco G (2007) Threats to the cerrado remnants of the state of Sao Paulo, Brazil. Sci Agric (Piracicaba, Brazil) 64:355-363

Elseroad AC, Rudd NT (2011) Can imazapic increase native species abundance in cheatgrass (Bromus tectorum) invaded native plant communities? Rangeland Ecol Manag 64:641-648

Evans RA (1961) Effects of different densities of downy brome (Bromus tectorum) on growth and survival of crested wheatgrass (Agropyron desertorum) in the greenhouse. Weeds 9:216-223

Harris GA (1967) Some competitive relationships between Agropyron spicatum and Bromus tectorum. Ecol Monogr 37:89-111

Hempy-Mayer K, Pyke DA (2008) Defoliation effects on Bromus tectorum seed production: implications for grazing. Rangeland Ecol Manage 61:116-123

Herrick JE, Jones TL (2002) A dynamic cone penetrometer for measuring soil penetration resistance. Soil Sci Soc Am J 66: $1320-1324$

Hulbert LC (1955) Ecological studies of Bromus tectorum and other annual bromegrasses. Ecol Monogr 25:181-213

Humphrey LD, Schupp EW (2001) Seed banks of Bromus tectorumdominated communities in the Great Basin. West N Am Nat 61:85-92

Johnston DB (2011) Movement of weed seeds in reclamation areas. Restor Ecol 19:446-449

Kelrick M (1991) Factors Affecting Seeds in a Sagebrush-Steppe Ecosystem and Implications for the Dispersion of an Annual Plant Species, Cheatgrass (Bromus tectorum L.). Ph.D. dissertation. Logan, UT: Utah State University. 206 p

Kyle GP, Beard KH, Kulmatiski A (2007) Reduced soil compaction enhances establishment of non-native plant species. Plant Ecol 193: 223-232

Kyser GB, DiTomaso JM, Doran MP, Orloff SB, Wilson RG, Lancaster DL, Lile DF, Porath ML (2007) Control of medusahead (Taeniatherum caput-medusae) and other annual grasses with imazapic. Weed Technol 21:66-75
Mangold J, Parkinson H, Duncan C, Rice P, Davis E, Menalled F (2013) Downy brome (Bromus tectorum) control with imazapic on Montana grasslands. Invasive Plant Sci Manage 6:554-558

Monty A, Brown CS, Johnston DB (2013) Fire promotes downy brome (B. tectorum) seed dispersal. Biol Invasions 15:1113-1123

Morris C, Monaco TA, Rigby C (2009) Variable impacts of Imazapic on downy brome (Bromus tectorum) and seeded species in two rangeland communities. Invasive Plant Sci Manage 2:110-119

Ostlie MH, Howatt KA (2013) Downy brome (Bromus tectorum) competition and control in no-till spring wheat. Weed Technol 27: 502-508

Owen SM, Sieg CH, Gehring CA (2011) Rehabilitating downy brome (Bromus tectorum)-invaded shrublands using imazapic and seeding with native shrubs. Invasive Plant Sci Manage 4:223-233

Prevey JS, Germino MJ, Huntly NJ, Inouye RS (2010) Exotic plants increase and native plants decrease with loss of foundation species in sagebrush steppe. Plant Ecol 207:39-51

Reinsch CH (1967) Smoothing by spline functions. Numer Math 10: 177-183

Rivera D, Jauregui BM, Peco B (2012) The fate of herbaceous seeds during topsoil stockpiling: restoration potential of seed banks. Ecol Eng 44:94-101

Roundy BA, Hardegree SP, Chambers JC, Whittaker A (2007) Prediction of cheatgrass field germination potential using wet thermal accumulation. Rangeland Ecol Manage 60:613-623

SAS Institute Inc (2012) SAS/GRAPH ${ }^{\circledR}$ 9.3: Reference, Third Edition. Cary, NC: SAS Institute Inc. $2082 \mathrm{p}$

Sbatella GM, Wilson EG, Enloe SF, Hicks C (2011) Propoxycarbazonesodium and imazapic effects on downy brome (Bromus tectorum) and newly seeded perennial grasses. Invasive Plant Sci Manage 4:78-86

Sheley RL, Carpinelli MF, Morghan KJR (2007) Effects of imazapic on target and nontarget vegetation during revegetation. Weed Technol 21:1071-1081

Thill DC, Schirman RD, Appleby AP (1979) Influence of soil-moisture, temperature, and compaction on the germination and emergence of downy brome (Bromus tectorum). Weed Sci 27:625-630

Thompson PJ, Jansen IL, Hooks CL (1987) Penetrometer resistance and bulk density as parameters for predicting root system performance in mine soils. Soil Sci Soc Am J 51:1288-1293

Wick AF, Stahl PD, Ingram LJ, Vicklund L (2009) Soil aggregation and organic carbon in short-term stockpiles. Soil Use Manage 25:311-319

Wicks GA (1997) Survival of downy brome (Bromus tectorum) seed in four environments. Weed Sci 45:225-228

Received January 2, 2014, and approved March 9, 2015. 